This item was submitted to Loughborough's Research Repository by the author.

Items in Figshare are protected by copyright, with all rights reserved, unless otherwise indicated.

\title{
Megaregions reconsidered: urban futures and the future of the urban
}

PLEASE CITE THE PUBLISHED VERSION

http://dx.doi.org/10.4337/9781782547907.00016

\section{PUBLISHER}

Edward Elgar @ John Harrison and Michael Hoyler

VERSION

AM (Accepted Manuscript)

LICENCE

CC BY-NC-ND 4.0

REPOSITORY RECORD

Harrison, John, and Michael Hoyler. 2019. "Megaregions Reconsidered: Urban Futures and the Future of the Urban". figshare. https://hdl.handle.net/2134/16583. 


\section{Megaregions reconsidered: urban futures and the future of the urban}

John Harrison and Michael Hoyler

\subsection{An introduction to (more than just) a debate on megaregions}

We live in a world of competing urban, regional and other spatial imaginaries. This book's chief concern has been with one such spatial imaginary - the megaregion. More particularly, its theme has been the assertion that the megaregion constitutes globalization's new urban form. Yet, what is clear is that the intellectual and practical literatures underpinning the megaregion thesis are not internally coherent and this is the cause of considerable confusion over the precise role of megaregions in globalization. This book has offered one solution through its focus on the who, how and why of megaregions much more than the what and where of megaregions. In short, moving the debate forward from questions of definition, identification and delimitation to questions of agency (who or what is constructing megaregions), process (how are megaregions being constructed), and specific interests (why are megaregions being constructed) is the contribution of this book.

The individual chapters have interrogated many of the claims and counter-claims made about megaregions through examples as diverse as California, the US Great Lakes, Texas and the Gulf Coast, Greater Paris, Northern England, Northern Europe, and China's Pearl River Delta. But, as with any such volume, our approach has offered up as many new questions as it has provided answers. In this concluding chapter, we 
identify some of these questions as part of an ongoing reconsideration of megaregions and reformulation of a programme of research for those of us interested in megaregions and global urban studies more broadly.

One of the main unresolved questions to arise out of this book is the status and position of the 'megaregion' within global urban studies. This extends much further than the immediate focus of this book, so one of our aims in this final chapter is to connect the contribution(s) of this collection to contemporary debates centred on urban futures and the future of the urban. The book has presented multiple pathways into the megaregion debate and we have identified four to develop further in this chapter, which are: (1) competing or complementary spatial imaginaries; (2) megaregional glocalization; (3) utopian/dystopian urban dreams; and (4) urban history, periodization and temporality.

To foreground this, we begin with three examples which caught our eye in the short period we were writing this chapter. They serve as an important reminder both of the continuing influence of megaregions within popular public discourses and the need for the type of more critical analysis that this book promotes.

\subsubsection{The Cali Baja 'Megaregion'}

In October 2013, David Mayagoitia, Chairman of the Tijuana Economic Development Corporation extolled the virtues of a megaregion spanning the US-Mexican border when officially launching the Cali Baja Binational Megaregion Initiative (http://www.calibaja.net/cbdb/p/): 
What we're trying to do is promote investment ... We want to create a binational economic development entity that actually promotes the whole region as a single group. The [US-Mexican] border only represents a line that we have to cross on a daily basis. What we would like to do is expand our region to include Los Angeles, because why not? Why not create a picture of what we want to be, and strive for that picture. Why not be Hong Kong and Shenzhen? (quoted in Connor, 2013)

Looking beyond the goal of investment and the fact that this is clearly indicative of how the geoeconomic logic for promoting the competitiveness of megaregions is putting megaregionalism centre stage of political action, what marks this example out among the many others we could have chosen is that Cali Baja is a cross-border region. Located on the US-Mexico border, Cali Baja is geographically proximate to, but politically detached from, the US megaregions. This is important for two reasons. On the one hand, Tijuana, Mexico is only one mile from the US border so, for Mayagoitia, playing down the significance of the border while playing up the potential for a binational economic development entity favours Cali Baja's inclusion alongside Cascadia as a cross-border megaregion within the discursive framing of US megaregions. ${ }^{1}$ On the other hand, Tijuana is located just 25 miles from San Diego and 140 miles from Los Angeles: expanding to include Los Angeles not only brings the outside in, to make the case stronger for a Cali Baja megaregion, it takes the inside out, because Cali Baja would by the same token become part of an already existing South California megaregion (Harrison and Hoyler, 2015, Figure 1.1). 
Quite clearly, there are strong motivating factors for Mayagoitia, Tijuana and Cali Baja to pursue megaregionalism as both an economic and political strategy. But while they can seek to influence the discursive framing of megaregions what they cannot do is change it. They are on the fringes economically, while politically they are excluded. On the face of it they are disempowered by the discourse of US megaregions. Yet, in and through the creation of a megaregional space they are entering the possibility of engaging and exerting influence over other centres of social power. Facing up to this challenge, Mayagoitia goes on to add:

There's really no rules, there's really no set manual to set up a mega-region. Things sort of evolve and happen, and you respond to those things. As you go through this process, you begin to realize that collaboration makes you stronger ... It makes people listen to what you have to say. (quoted in Connor, 2013)

If the earlier statement focused on the 'what' and 'where' of the Cali Baja megaregion, the remainder of this section has focused on the 'who', the 'why' and the 'how' in relation to megaregions. The opening to this second statement is pertinent because although megaregions have fast become an officially institutionalized task for policy elites the world over, megaregions are not universally accepted as 'official' state/governmental policy. The result is less prescription than might otherwise be the case, meaning the question of who constructs megaregions and why becomes even more important. In this way the final sentence becomes the most significant. It shines a light on what is the ultimate goal of megaregionalism as a political project - exerting influence in and through megaregions. The open question in this example and many 
others too are: who are the 'people', what is (and whose is) the message, and perhaps most critical of all, if successful who, what and where is likely to gain/lose the most as a result?

10.1.2 The Hampton Roads-Richmond 'Megaregion'

In December 2013 the unfolding process of megaregionalism saw actors located in another space which currently finds itself 'off' the politically-constructed map of megaregions ponder its position within national and international circuits of globalized capital accumulation. Located in the US State of Virginia, Hampton Roads and Richmond are strategically positioned between two megaregions. 100 miles to the north of Richmond is Washington, DC and the southern tip of the Northeast Megaregion (Gottmann's (1961) 'megalopolis'). To the south is Raleigh, the northernmost city in the Piedmont Atlantic Megaregion identified by the Regional Plan Association (RPA) (2006), located 180 miles from Hampton Roads. As a result, Hampton Roads and Richmond find themselves located on the fringes of US megaregionalism as it is politically constructed. This has not gone unnoticed, particularly among local business leaders. More interesting is the response:

Businesses can certainly do this on their own. We don't need the formality of a megaregion, but it's a perception. We certainly need to look united to be competitive to our brethren to the north and south who have already created those megaregions that are competing better than we are now. (Tom Frantz, Hampton Roads Business Roundtable, quoted in Bozick, 2013) 
Unlike Cali Baja, where the modus operandi is to create a formal megaregion, the approach favoured by business leaders in Hampton Roads implies seeking the benefits of operating like a megaregion in an economic sense (and signified to the wider world through a merger of metropolitan statistical areas (MSAs)) but without the formality of being a megaregion in the political sense. This example demonstrates that the question is not always where, why and how actors choose to engage in the construction of megaregions but why some choose to engage more than others. In the case of Hampton Roads and Richmond do they choose not to engage in attempts to politically construct a megaregion because they recognize they will not be permitted into the exclusive club of 11 megaregions which the Regional Plan Association (2006) have placed on a pedestal as America's new urban hierarchy? Is it that business sees the whole megaregion idea as being somehow abstract and of no immediate consequence other than in marketing terms? Or is it that they can see the potential importance in terms of attracting business and infrastructure investment, thus engaging with the megaregion concept but only on their own terms? These are the important but often unanswered questions which we argue the more critical perspective promoted by this book can and need to avail answers to if we are to move forward with megaregions as a key component of global urban studies.

Cali Baja and Hampton Roads-Richmond appear to adopt very different strategies yet they both respond to the same feeling of being disempowered by megaregionalism, and globalized urbanization more broadly. Moreover, their different strategies aspire to much the same outcomes, that is, to create a mechanism which can lobby on behalf of certain capitalist interests. This neoliberal pro-growth model sees 
Cali Baja and Hampton Roads-Richmond both using the 'megaregion' to engage extraregional actors and seek to exert influence over them, all in order to fix mobile capital investment within their region and facilitate growth. More specifically, local actors in Hampton Roads-Richmond have mobilized around one particular issue - securing money for local transportation projects. Irrespective of whether you are a national organization, such as the RPA with its America 2050 initiative, or a local group of business leaders, megaregions are a leveraging tool particularly when it comes to funding transportation projects:

In terms of federal dollars, the bigger attention you attract, the more leverage you have. (Tom Frantz, Hampton Roads Business Roundtable, quoted in Bozick, 2013)

The clout of a bigger region could bring more attention and help all of the things going on just snowball a little further. [Adding] If we're not in the top MSA regions, they're not thinking about us. (Russell Held, Senior Vice President, Virginia Port Authority, quoted in Bozick, 2013)

The appeal of megaregions is not only the end goal. Megaregions provide a narrative, a story board on which local issues are played out. The trend towards enlarged urban scales in policymaking is less about planning and governing at that scale and more about the creation of 'spaces of engagement' - the space in which the politics of defending and enabling certain place-specific, essential interests unfolds (Cox, 1998). From megalopolis to megaregion, European Spatial Development Perspective to 
America 2050, Cali Baja to Hampton Roads-Richmond, the story of megaregions is firmly rooted in the creation of a specific narrative and perception of place ${ }^{2}$. To reiterate our earlier point, the construction of megaregions should be seen as a spatial strategy and, by implication, a deeply politicized act. The creation of a megaregional space is a tactic employed by actors with place-specific interests, actors who are motivated at a particular moment in time to create a space to enhance or defend those very interests. We argue that timing is the important but often overlooked dimension of megaregional analysis - a mistake caused by too much focus on the what and where of megaregions, rather than the who, how and why - and it is also a key dimension in our third example.

10.1.3 A New PAR-LON ‘Megaregion’?

In January 2014, an open letter to Boris Johnson, Mayor of London, saw Anne Hidalgo, Deputy Mayor of Paris and mayoral candidate in the March 2014 elections, claim that:

London is a suburb of Paris and Paris is a suburb of London ... From Tokyo, Shanghai, Lagos or Rio - cities that will have more than 20 million inhabitants by 2030 - Greater London and Paris Grand, with a combined population of 20 million, may well be seen as a single conurbation. Indeed, in this not-too-distant future, London and Paris together could be seen from Asia, Latin America or Africa as ... possessing a critical mass of resources to reckon with. That's if we can find a way to collaborate effectively. (Hidalgo, 2014, p. 1) 
There are two important aspects to this: the first is spatial, the second is temporal. Spatially, Hidalgo chooses the term conurbation over megaregion, yet the argument still holds that this is a further example of endeavours to politically construct a megaregional space of engagement in order to secure certain economic interests from external threats which seek to undermine or dissolve them. Paris is reaching out to London, much like Cali Baja is reaching out to San Diego and Los Angeles. Yet, what marks this example out is that by standard definitions Paris already has the critical mass to consider itself a megaregion (Florida et al., 2008). Two closely related questions immediately present themselves. The first is why 20 million? This is the global benchmark set by organizations such as UN-Habitat for megaregions, so this might be a valid reason were it not that Paris and London as metropolitan-scaled cities are both approaching a population of 20 million already. This suggests it must be something else, which is why the second question we must ask is why London?

Perhaps, ultimately this example has more to do with French territorial politics and an awareness of Anne Hidalgo's position as the Socialist Party candidate for the 2014 mayoral elections. The challenge for Hidalgo was to position herself for the forthcoming elections as a future mayor with global outlook, against a background where the political party she represents is, under President François Hollande, implementing a 75 per cent 'super tax' on employers paying salaries over 1 million euros per annum. Among Parisian elites the fear is this super tax will spark an exodus of wealthy French millionaires and talented entrepreneurs from Paris to London (where the top rate of tax is currently 45 per cent) and undermine the status of Paris as a globally competitive city. Coming less than one month after Hollande's super tax was approved by France's highest court, the timing of Hidalgo's quotes are therefore not insignificant. 
Indeed, the timing of this very public courting of Johnson and London becomes even more important to this story when we consider they came just four days after she had told a gathering of Parisian-based Anglo-American reporters how 'London is in some ways a suburb of Paris' (quoted in Samuel, 2014, p. 1). What we arrive at is the competitive positioning of Paris vis-à-vis London clearly giving way to what can be interpreted as a conciliatory move to espouse a more cooperative spirit between London and Paris. This certainly appears to suggest Hidalgo's very public courting of Johnson and London owes much more to French politics than representing a genuine attempt to plan and govern at the scale of the megaregion. Put bluntly, the megaregion is not the story in this example; it is just the vehicle for communicating a particular story to its chosen audience. What we see is the use of the megaregion idea at a time that is politically expedient. The result is what will no doubt amount to a very fleeting, temporary attempt at constructing a megaregional space of engagement.

This example demonstrates that only in asking the 'why' question does the temporal dimension come to the fore. Therefore, it is not sufficient simply to ask the 'why' question in a spatial context (Why 20 million? Why London?), we need equally to be asking it in a temporal context (Why now?).

\subsection{Megaregional futures and the future of the megaregion}

10.2.1 (Re)new(ed) spatial imaginaries: competing or complementary?

As we noted in our introductory chapter, megaregions are just one of an increasingly large number of competing spatial imaginaries which purport to reflect globalization's 
new urban form. There are four important aspects to this which this book has confronted. The first is why, from all the competing spatial imaginaries that exist to explain globalization's new urban form, megaregions have emerged to become one of the more powerful, persuasive, and dominant imaginaries. The chapters in this book point to a divergence of opinion depending on whether you take geoeconomic or geopolitical arguments as your starting point. For some, megaregions $d o$ constitute globalization's new urban form. They are the spatial manifestation of economic activity, the economic motors in today's quicksilver global economy, the newest incarnation of what agglomeration economists argue is incontrovertible in globalized urbanization and that is the trend which sees an ever smaller number of increasingly large urbanized clusters surging ahead to dominate the global economy (Florida, 2014). The formula appears to be bigger is better (Hesse, 2015). While this may in part explain the emergence of some megaregions, for others, the new map of megaregions is constructed politically. While not denying the economic logic, our book highlights the presence of so many megaregions is the result of a more calculated act of political lobbying to ensure certain places appear on the map and are included alongside those urban economies they aspire to be considered with. Megaregions could arguably be seen as the latest example of a new regional theory being led, in large part, by policy developments (Lovering, 1999).

The second aspect follows on directly from the first. When is a megaregion a megaregion? The interventions in this book provide further illustration that megaregions mean different things, to different people, in different contexts. The politicized nature of megaregion formation leads to the definition becoming blurred. It is for this reason that our own contribution sought to reaffirm megaregions as comprising two or more 
interrelated urban systems (Harrison and Hoyler, 2015). This does not address the question of whether these megaregions are realities or imaginaries but it does help distinguish megaregions from other spatial forms (Harrison and Hoyler, 2015, Table 1.1). Defining the parameters is important because it ensures that as researchers we begin with the same objects under our consideration.

This leads straight to a third aspect. Although trying to distinguish megaregions from other spatial forms is important for analytical purposes, how social processes are spatially configured is highly complex, undeniably messy and always in a state of flux (Harrison, 2013; Taylor et al., 2013). While some megaregional spaces may well emerge from how those social processes are configured by globalizing forces, in many cases they are being imposed as part of strategic attempts by actors to make competitiveness-oriented interventions (e.g. funding large-scale infrastructure projects, establishing new forms of public-private partnerships) designed to change these patterns to the advantage of their location. The key point here is that some megaregions exist in institutional form but not in spirit, others exist in spirit but not in institutional form. One of the questions which require further research is uncovering where the evidence supports the creation of a megaregion as opposed to examples where evidence is being found to justify a megaregion. This is important because it raises the prospect of megaregional legitimacy, that is, the degree to which places can legitimately identify as a functioning megaregional space as opposed to a formal megaregional space where there is little evidence of actually existing processes of megaregionality.

The final point concerns when and where megaregions complement or contradict the many other imaginaries which exist to account for (different aspects of) globalization's new urban form. It might sound somewhat paradoxical to argue this but 
the danger with the 'brave new world of megaregions' (Smas and Schmitt, 2015) is we focus too much on the megaregion itself. We have observed a tendency in much of the work that has taken place on megaregions to - either consciously or subconsciously neglect engaging with other competing urban and regional imaginaries. Privileging megaregions over other spatial imaginaries serves to boost the profile of megaregions, but in so doing it presents a compelling narrative that only tells part of the story. Very much akin to Jessop et al.'s (2008) account of the prevalence of 'one-dimensionalism' in social-scientific thinking over recent decades, one consequence of this privileging of megaregions is a megaregional world thesis which is guilty of overplaying its hand through exaggerated claims to its exceptionalism. This produces a somewhat insular, inward looking, debate, which focuses on a single spatial imaginary - the megaregion. Our point is that it is wrong to study megaregions without considering them in the broader contours of global urban studies.

It goes without saying that the study of megaregions is not alone in this. In fact these four aspects point in the direction of a more general concern with contemporary studies of urban and regional formations. Too often it seems that the 'cult of newness' (Schafran, 2015) results in a tendency towards providing snapshots of a single fragment of the spatial configuration of urban-regional space at any one point in time. The failures rest in not considering the different fragments and whether they can be spatially aligned to form a coherent configuration or positioning the time-frame under consideration within longer historical trajectories. On the spatial aspect of this, it is becoming increasingly important to account for the space-times in which different urban and regional imaginaries are complementary, contradictory, overlapping, or competing. This is because endeavours to overcome the spatial tensions and contradictions inherent 
within the capitalist system are resulting in increasing numbers of (re)new(ed) spatial imaginaries (Harrison and Growe, 2014; Hoyler et al., 2006). We also see derivations, mutations, and realignments of spatial concepts - such as Smas and Schmitt's (2015) idea of 'soft megaregions' - so the challenge is not simply to identify megaregions, but to recognize their position, role, and status within the broader spectrum of urbanregional space. The following quote emphasizes this point and provides a useful framing for the context in which future studies of megaregions (and other spatial imaginaries) need to be considered:

The overall configuration of regions within the world market cannot be planned with any certainty of success. On the contrary, given that there are many competing regional imaginaries (as well as other spatial or spatially-attuned imaginaries), the configuration is the unintended, unanticipated, and, indeed, 'messy' result of the pursuit of numerous regional projects in conjunctures that cannot be grasped in all their complexity in real time. (Jessop, 2012, p. 26)

This observation underpins our argument that megaregions always need to be considered within the broader contours of global urban studies. Moreover, it is why, for us, this book serves as an introduction to a debate around megaregions, while simultaneously contributing to broader debates centred on urban futures and the future of the urban. Put simply, in producing this book it has become clearer to us that focusing on one spatial unit or imaginary provides an ever decreasing lens on the totality of our globalizing urban world. The chapters in this volume provide an indication of what can be achieved when we position a single spatial unit/imaginary 
within these broader configurations of urban-regional space. The difficulty of the task which lies ahead is not lost on us, but if we are to move forward in any meaningful way with global urban studies it is one we must confront conceptually, methodologically and empirically.

10.2.2 Megaregional glocalization

Whether megaregions exist in space and time is one thing. It is another thing whether megaregions have any meaningful impact on society. Our starting point is to recognize that processes of globalized urbanization and megaregionality are far more partial than the narrative would suggest. Yet, accounts extolling the 'continuity' and ‘interpenetration’ of urban-economic processes across all geographic space abound (Scott, 2012), most notably Brenner's (2013) theory of 'planetary urbanization'. So what is going on? Here we turn to the work of Wachsmuth, who, in a critical exposé of the perseverance of the city as an ideological concept in globalization, argues that 'while urbanization might now be a planetary process, it is not lived or experienced as one' (2014, p. 78). We are particularly sympathetic to this perspective because, as this book has shown, the rise of megaregions 'brings us inevitably to the question who is, and who is not, actually affected by megaregions?' (Smas and Schmitt, 2015, p. 167). More to the point, it furthers our own contention that we need increasingly to focus on the questions of who (is affected), how (they are affected) and why (they are affected) in relation to megaregions.

In this section we want to broaden the spatial focus of megaregional research to consider the extent to which processes of megaregionality are being represented in a 
singular globalized form when in fact they appear to be experienced in distinctly localized ways. Schafran's (2015, p. 90) intervention is timely because it emphasizes the need to 'rethink the geography of megaregions'. He offers two heuristic devices to help advance the geography of megaregions. In the first, Schafran's distinction between 'megaregional spaces' and 'spaces of the megaregion' enables us to consider two distinct, yet interrelated, forces which are always present in, and in conflict across, megaregions. On the one hand, there are integrative forces which seek to reassert the coherence, legitimacy and validity of the megaregional space, often through an evolving discursive frame. This is also reflective of the argument that all (megaregional) space is exposed to urban-economic processes. On the other hand, there are differential forces which ensure the exposure to megaregionality is geographically uneven across the megaregional space. This calls for both macro- and micro-level analysis of megaregions because the balance between these forces is important for recognizing how megaregionalism is experienced in places across the megaregion at any point in time ${ }^{3}$. In this book we see many examples of this type of macro- and micro-level analysis of megaregions. Smas and Schmitt (2015), for example, point to attempts in Northern Europe to establish 'Norden' across spaces which share cultural, historical, and political commonalities, yet are now experiencing diverging development paths in respect of territorial policy and politics, and urban and regional planning. Likewise Glass (2015) draws attention to the reinvention of the US Midwest as the Great Lakes megaregion in an attempt to preserve the legitimacy of this imagined space as a viable political authority. However, these efforts neglect to consider how the tens of thousands of extant spaces of local governance operating across the Great Lakes mean the megaregional space is both fragmented and - unlike some other megaregions, such as 
Gottmann's megalopolis - discontinuously urbanized. Meanwhile Fleming (2015) shows how megaregionalists are reinventing the discursive framing of megaregions from a singular logic of megaregional competitiveness to a more pluralized vision where megaregions are deemed important for resilience, climate change adaptation, and economic development in order to preserve megaregional spaces. Then, later in his chapter, Fleming goes on to test economic integration between the Texas Triangle and Gulf Coast megaregions, observing how the Houston and Beaumont Metropolitan Statistical Areas - as the only two regions which are included in both megaregions appear to share economic characteristics with both the Texas Triangle and Gulf Coast megaregions. What we see in each of the three examples is how megaregionalism is itself a reflection of the defining features of global urbanization - namely, accelerated processes of global integration being matched by greater local differentiation - hence the need for more macro- and micro-level analyses which seek to understand the dynamics and interplay between the integrative and differential forces impacting upon megaregional space and spaces of the megaregion.

Schafran's (2015) second heuristic device is the recovery and extension of Taylor and Pain's (2007) framework for conceptualizing processes of urban expansion. Distinguishing between vertical (or primate) megaregional systems ('Process A'), horizontal megaregional systems ('Process B'), and hybrid megaregional systems ('Process A + B') is critical to understanding how megaregionalism is differentially experienced because each has different material and infrastructural requirements. Therefore, where capital is spatially fixed - and by implication who is most affected - is dependent on the economic processes shaping the urban fabric. But we should not forget that when, where and how capital is spatially fixed remains a deeply politicized 
act. Megaregionality, real or otherwise, is clearly used to legitimize certain investment decisions relating to infrastructure, housing, and social reproduction, and by implication who is being affected most / least by megaregionalism in action.

Our broader point is that the challenge to rethink the geography of megaregions needs to include the spatial and experiential geographies of megaregions. Put simply, the geographical map of megaregional space is fundamentally different to the geographical map of where megaregionality is experienced. Where the former appears relatively coherent and stable over time the latter is partial, fragmented, uneven, and constantly in a state of flux. The important point to make is that being included on the politically-constructed map of megaregions does not mean you experience megaregionalism, likewise, just because you are not on the megaregional map does not mean you do not experience the effects of megaregionality. So although arguments pertaining to a world of megaregions - or even a 'megaregional world' (cf. Storper, 1997) - might appear convincing when viewing a map of megaregional spaces, mapping spaces of megaregionality would appear to cast doubt on some of the claims made on behalf of megaregions representing globalization's new urban form.

10.2.3 Urban dreams: utopia or dystopia?

In his latest book, Keys to the City, the influential economic geographer Michael Storper offers a revealing insight into the current state of global urban economic development:

The geographical churn, turbulence, and unevenness of development, combined with the sheer scale of urbanization, will make city-region development more 
important than ever - to economics, politics, our global mood, and our welfare. And managing it will pose one of the most critical challenges to humanity. The winning side of the process will excite us and motivate talent, but the losing side will create displacement and anger, both within and between countries. (Storper, 2013, p. 4)

What drew our attention to this quote is the way in which it points to the type of megaregional research we advocate. In the opening few words, we see that the emphasis is firmly on the scale of urbanization and its resulting spatial form. Yet, what follows shows us how the question of what is the spatial form of large-scale urbanization and where are they located is largely inconsequential. These questions only become of consequence when we come to understand their impacts - on society, the economy, politics and the environment. But more than this, urban studies are at their most powerful when questions of agency and process are to the fore. Storper's reference to 'managing it' is most revealing in this regard, as is his distinction between the capacity for globalized urbanization to excite us and to vex us, because the clear inference is that actors and agency are active in determining the winners and losers. They have a critical role in deciding when, where, and at what pace development occurs, who benefits, and ultimately what the consequences are of globalized urbanization.

Although Storper stops short of adjudicating on what he sees as the balance between excitement and anger, winners and losers, the wider literature in global urban studies is reverberating with utopian and dystopian accounts of near urban futures. Briefly illustrating the former, Ed Glaeser (2011, pp. 9-10) argues in his book, Triumph of the City, that 'not all urban poverty is bad' because cities attracting poor people 
'demonstrates urban strength, not weakness ... a fact of urban life that should be celebrated'. Alongside this, in his book Extraordinary Cities, Peter Taylor (2013) speaks of the 'unleashing of human potential' within cities across the ages, a picture which presents the city as the solution rather than the cause or the victim. We can contrast these accounts with those of Mike Davis (2006), in his book Planet of Slums, and David Harvey (2010) in The Enigma of Capital, who both offer up gruelling, often apocalyptic, depictions of contemporary global urbanization, reminiscent of Victorian Europe only on a vastly bigger scale. What this speaks to is a broader urban narrative, one which the geography of megaregions detailed in this book reflects, but also contributes to.

In our opening chapter we pointed to the clear difference among the forefathers of megaregional research on the future urban condition, with Patrick Geddes and Lewis Mumford both viewing large-scale urbanization as unsustainable, while Jean Gottmann held a progressive view of the economic and social potential of the expanded urban form. It was not lost on us as we worked to produce this volume that much of the new and emerging urban literature continues to be written through the megalopolis-tinged spectacles of these antecedent accounts. One example of this is Planet of Slums, in which Mike Davis (2006) opens with the following epigraph: 'Slum, semi-slum, and superslum ... to this has come the evolution of cities'. These are the words of Patrick Geddes, quoted by Lewis Mumford in The City in History (1968, p. 464), and now used in the 21 st century by Davis to underscore his despairing account of global urbanization. Indeed, it is not only the antecedent work on megaregions which gives inflection to these contemporary urban debates; much reference is also made to the foundational work on megaregions. Continuing with the example of Planet of Slums, 
Davis equates megaregions with the 'Leviathan', before proceeding to highlight an OECD account extolling the virtues of an embryonic West African megaregion that will soon be 'comparable to the U.S. east coast' (Cour and Snrech, 1998, p. 94; see also UNHabitat, 2010), and declaring: 'Tragically, it probably will also be the biggest single footprint of urban poverty on earth' (Davis, 2006, p. 6).

Our own starting point was a reading of the megaregional literature which appeared, on the surface at least, to concur with Brendan Gleeson's recent commentary on the literature contributing to the 'urban age' thesis: 'The overall cast is ... broadly similar - optimistic and generally of the view that cities have immanent trends, even laws, which define their possibilities' (Gleeson, 2012, p. 932). Certainly the foundational work on the resurgent interest in megaregions portrayed an unquestionable logic linking megaregions to global economic competitiveness. Our more critical approach to considering megaregions provides a different perspective. Nonetheless, it would be wrong to say that our book only offers criticisms and negative connotations. None of the contributions suggest the megaregion is an empty vessel. Each contribution highlights aspects of the megaregion thesis which are arguably in need of more thorough examination, exposing potential fault lines in the logics which have given rise to the more optimistic claims regarding the role of megaregions in globalization. Moreover, the authors endeavour to demonstrate through their own research new ways of thinking about megaregions; ways of thinking that develop the megaregion into a more robust concept and focused policy tool. Four points immediately present themselves across the chapters.

The first of these concerns competitiveness. Nearly all the work that has taken place on megaregions has concentrated on linking megaregions to competitiveness. 
Indeed it has been impossible to escape inherent notions of 'policy boosterism' dominant in megaregion analysis to date (Hesse, 2015). Nevertheless, Wachsmuth's intervention suggests how:

$[C]$ ontrary to the new prevailing wisdom ... US megaregions are not emerging as competitive actors in the global economy, but rather are better understood as strategic terrains upon which a multitude of differently scaled competitiveness strategies are being enacted. (Wachsmuth, 2015, p. 52)

What follows from this line of thinking is that the 'unimpeachable logic' connecting megaregions to global economic competitiveness is in the process of being challenged, discredited, even broken (Glass, 2015). This has far reaching consequences for the future of the megaregion concept in both intellectual and practical debates because without the link to competitiveness the megaregion thesis lacks its 'big idea'. Nevertheless, what we have witnessed in recent years are proponents of the megaregion concept moving to broaden the evidence base for megaregions beyond the solely geoeconomic discourse of competitiveness (Regional Plan Association, 2013; Ross et al., 2015; Seltzer and Carbonell, 2011). This is particularly prevalent in the United States. Fleming (2015) details how Superstorm Sandy came to expose just how susceptible megaregional infrastructure was to external threats when it struck the US east coast in 2012 . Yet the damage caused by the storm was to open up a new opportunity as proponents of megaregional planning moved to strategically position megaregions prominently within (re)emerging debates around resiliency planning, energy infrastructure, and environmental/climatic change. This demonstrates one 
recurring feature of megaregional applications, which is they are not spatial, temporally, or thematically fixed. Like other spatial constructs and processes, megaregions and megaregionality have stronger / weaker resonances in particular places, at particular times, and in relation to particular themes. It also demonstrates that megaregions do not just need to strategically position themselves in national and international circuits of capital accumulation; they also need to compete with other spatial imaginaries to embed themselves in a multi-level system of local, regional, national and international governance. This requires understanding both the geoeconomics and geopolitics of megaregionalism. Indeed, as Margit Mayer (2008, p. 416) so eloquently encapsulates:

Put bluntly: it is never the spatial form that acts, but rather social actors who, embedded in particular (multidimensional) spatial forms and making use of particular (multidimensional) spatial forms, act. The relevance of a particular spatial form either for explaining certain social processes or for acting on them can be measured only from the perspective of the engaged actors. Thus, in order to define criteria for the relevance of (a specific form of) spatiality, we need to start, both in our theoretical endeavours as well as in political practice, from concrete social processes and practices rather than reifying spatial dimensions.

It is for these reasons that one of the main contributions of this book is its attempt to move the megaregional debate forward from questions of definition, identification and delimitation to questions of agency (who or what is constructing megaregions), process (how are megaregions being constructed), and specific interests (why are megaregions 
being constructed) through an analysis of the tactics, strategies and mechanisms employed by actors to put megaregions on the political-economic map.

The second of these concerns follows logically from the first. Successfully embedding megaregions geoeconomically and geopolitically does much to instil optimism that they are coming to represent globalization's new urban form. Yet, it is the inability of actors to successfully position megaregions within a globalizing world economy and political system which is intermixing this optimism with a strong dose of scepticism. One of the biggest concerns is always past failure. This concern is taken up by Wheeler (2015, p. 99) especially, who quickly points out that in the United States experience tells us that "we can hardly plan at the regional scale, let alone for megaregions'. Once again drawing on the US context - but nonetheless with equal relevance to other geographic contexts - Glass develops this further, identifying two primary reasons why we are right to be sceptical about the rhetoric surrounding (mega)regional projects:

[C]onditions within the US preclude enactment of grand visions such as the megaregion. There are two key exigencies preventing the megaregion becoming reality. First are the political exigencies of American life.... [P]roponents of the megaregion must be capable of continually reasserting the value and need for this geography over the likely long time it will take for the megaregion notion to be enacted and granted political legitimacy. Added to those challenges are geographic exigencies. (Glass, 2015, p. 139) 
These geographic exigencies are the thousands of extant politico-administrative units which comprise our increasingly complex, multi-scalar political systems; the very systems into which social actors have to embed megaregions before arguably the megaregion approach can begin to match some of the optimism held by its key proponents.

Our third concern returns us once again to this important distinction between 'megaregional spaces' and 'spaces of the megaregion' (Schafran, 2014). We are strong advocates of combining this type of macro- and micro-level analysis because adopting one or the other can result in an overly utopian or dystopian perception of megaregions. It might be argued that the evidence in support of megaregions being globalization's new urban form is at its strongest when considering megaregional spaces, because this is the lens through which megaregions are commonly presented as being internally coherent spaces. Similarly, it might be argued that the evidence which opposes megaregions being globalization's new urban form is at its strongest when considering the more localized 'spaces of the megaregion', because this is the lens through which the unevenness of megaregionality processes across megaregional space come to the fore.

Our fourth and final concern is that for all of this, we find ourselves left with one very simple question. What, if anything, has changed? We are forced to ask this question because the contributions to this book almost always return to this particular concern. Feverishly attempting to portray megaregions as something distinctly 'new' is nothing new (Taylor and Lang, 2004), and yet the evidence points towards megaregions being the latest phase in a long-running urban saga. As we and others have noted, there is certainly a trend towards 'bigger is better' in global urban analysis (Harrison and 
Hoyler 2015). Moreover, on competitiveness, it is argued that '[m]egaregions represent a heightening of the imperative towards interurban competition but at a new spatial scale' (Wachsmuth, 2015, p. 66; our emphasis), while on the environment it is being argued that 'rather than helping bring about more sustainable societies this new scale of [megaregional] planning is likely to accelerate what some climate change scientists have labelled BAU (“business as usual”) forms of development' (Wheeler, 2015, p. 97; our emphasis). The key point here is that new narratives seem to echo the same old narrative. What is new about megaregions is, for the most part, the scale of analysis and intervention. Otherwise much, and this includes the outcomes, appears to remain the same - only more ubiquitous, more intense, and on a much grander scale.

10.2.4 The missing dimension: urban history, periodization, and the temporality of megaregions

Taking stock of the 'urban age' thesis, Brendan Gleeson (2012, p. 942) concludes that 'popular urbanology reminds us that there is truly nothing new under the ever-glowing sun'. Certainly, feverish attempts by urbanists to account for globalization's evolving spatial form and function can lead to an unhealthy obsession with newness. Megaregions and the megaregion concept are illustrative of this trend: two of the founding intellectual contributions underpinning this resurgent interest in megaregions include claims to 'new data', 'new, natural economic units', 'new global terrain', 'new technology and innovation', 'new scale', 'new approach', 'new urbanism', 'new patterns', 'newly defined' and 'new agenda and paradigm' (Florida et al., 2008; Ross, 2009). While we do not wish to deny that some aspects of the megaregional thesis are 
indeed new, the trap is to over-emphasize what is new. One of the main aims of this book has therefore been to think about how to historicize the current situation with regard to megaregions.

In our introductory chapter we suggested the roots of today's megaregions concept go back to the beginning of the 20th century. One of the most pertinent points for us was to demonstrate the ebb and flow of the megaregion concept in the 20th century. This is important because it is easy to forget that the megaregion is one of the more durable spatial concepts in urban studies. Specifically in relation to functional urban areas, looking beyond the flotsam and jetsam of past and present experiments reveals 'world city', 'city-region' and 'megaregion' as the spatial imaginaries which are standing the test of time. At a time when we are being asked to consider why, when urbanization processes far exceed the city, the concept of 'the city' remains so tenacious (Wachsmuth, 2014), one of the aims of this book has been to consider why the megaregion concept continues to be renewed both intellectually and practically; withstanding the appearances and disappearances of so many other competing spatial imaginaries (cf. Taylor and Lang, 2004). In this way we agree with Hesse (2015, p. 30) that ' $[\mathrm{t}]$ he more popular this term and the associated concept is becoming, the more it seems useful to explore the question of where it comes from, what its meanings are, and whether it brings urban-regional policies forward or not' - only we would go further and say it is not only useful, it is essential. Our one note of caution is deciding which historical trajectory to embed megaregions in plays a critical role in determining the extent to which current interest in megaregions is seen to reflect the continuity or discontinuity of longer-term trends relating to urban expansion, urban development, and urban studies. Four points emerge from the contributions to this book. 
The first is the need for a more historical perspective of megaregions. In his contribution, Schafran (2015) claims contemporary megaregional research is 'ahistorical' and argues for a 'less economistic, more historical' - to which we would add, more political - approach to future studies of megaregions. The point being made is that too many studies concentrate exclusively on the here and now. They study what can be observed - namely the what and the where of megaregions - then typically project into the near and far future with little more than a passing acknowledgement to the antecedent work on megaregions and urban history more broadly. Our point is that megaregional research needs to look back as much as it looks forward, with the geography of megaregions seen more as an outcome than the beginning of something new. That said it is important to ask what type of historical perspective is necessary, and this is our second point. Nostalgic references to Gottmann, Geddes and Mumford are common in megaregional research but what the contributors to this book reveal is a much broader tradition of megaregional research, providing valuable empirical insights, conceptual elements, and theoretical provocations to animate and renew analyses of the megaregions. Indeed, this leads neatly on to a third point. What is revealing is that although many will agree with the need to position the current focus on megaregions within a much longer trajectory of megaregional research, there are very different views on what that historical trajectory should constitute: for Zhang (2015) it involves going back at least two millennia; Schafran (2015) to the late nineteenth century; while for Wachsmuth (2015) and Fleming (2015) the 1960s and 1970s hold the key. So as much as we advocate a more historical approach to researching megaregions, we caution that in so doing we need to consider why authors revisit certain points in history to make 
certain arguments in relation to current events. It is not simply a case of knowing when and who they select, but why and how they are selected.

This leads to the fourth and final point of why we need to adopt a more historical perspective in megaregional research. One answer is to ensure as researchers we do not repeat the same mistakes (Harrison, 2007; Schafran, 2015). But a second, more progressive, answer is the merits of periodization, an idea being brought to bear in Neil Brenner's latest writings on the spatial reorganization of economic and political power in globalization. For Brenner (2009, p. 134), periodization represents 'one of the most challenging and exciting frontiers' for research in global urban studies. This is because periodization confronts the necessary task of moving beyond temporally defined scaled moments of capitalist growth - that is, those claims to a 1990s 'regional', early-2000s 'city-regional' or late-2000s 'megaregional' scalar fix - which are presented as though they are internally coherent and consistent narratives of economic and political logic for how capitalism is organized in the current phase of globalization, to look in much more detail at how these spatial developments vary across time and space (see also Harrison and Hoyler, 2014). It is for this reason that our introductory chapter began by identifying how the megaregion has been prominent in different world regions at different points in history. We showed how the megaregion discourse was pervasive in Europe during the late 1980s and through the 1990s, in southeast Asia during the 1990s, before coming alive across North America in the mid-2000s, and is now seen emerging in Australia and Africa. The timing of this book is significant because it comes at a time when despite this long-held interest in the term and its associated concept in urban and regional studies, the megaregion is arguably of 'global' significance for the very first time in its history. Yet, that being said, one of the key 
findings from this book has been to show how its global significance and appeal does not necessarily equate to omnipresence.

\subsection{Coda: megaregions as globalization's new urban form?}

The megaregional urban form is not going to disappear any time soon. The question is whether the megaregion concept will survive with it. This is the dilemma, as we see it, arising from this book. The problem, as many of the contributions attest, is the megaregional thesis is built around a partial, largely economistic, reading of megaregions which has a tendency to neglect important temporal and political aspects of developments in megaregional form and function. To this end, one of the main outcomes of the book is to argue the case for a more deeply politicized and historicized account of megaregions. To be clear, our argument is not that megaregional research should somehow become less economic, rather that singular economistic readings of megaregional development are insufficient to account for globalization's urban form, and need to be complemented by the more political and historical investigations we advocate here. Indeed, one purpose of this book is to create space for debating megaregions in a more challenging and robust way, one which serves to refine, question, and, if necessary, debunk some of the claims made about megaregions from a purely geoeconomic perspective.

Let us be clear, we do not wish to see a withering away of megaregions in critical urban inquiry, but if the megaregion concept is to remain central to intellectual and practical developments in urban studies and urban policy it needs to be a more robust concept and framework. To do this we need to move beyond the theoretical 
myopia and exaggerated claims to newness which currently surround megaregions. We argue that this requires researchers to focus on the who, the how and the why of megaregions rather more than the what and the where of megaregions. Indeed, one of the main contributions of this book has been to extend research from questions of definition, identification and delimitation to questions of agency (who or what is constructing megaregions), process (how are megaregions being constructed), and specific interests (why are megaregions being constructed). More broadly, we believe the megaregional story detailed in this book is one which can illuminate certain aspects of currently topical debates around urban futures and the future of the urban. In our final statements we want to briefly touch on three broader contours of global urban studies that the content of this book contributes to.

The first contour relates to the production of new theory in urban studies. Part of a special issue on the future of city-regions, international urbanist, Ananya Roy (2009), argued the need for 'new geographies of theory' and 'new conceptual vectors' to understand the 21 st century metropolis, and evolving forms of globalized urbanization more broadly. It is time, she argues, to 'blast open theoretical geographies, to produce a new set of concepts in the crucible of a new repertoire of cities' (Roy, 2009, p. 820). This call to arms has certainly been taken forward in the intervening years, yet, for all that we agree with Roy's sentiments we cannot help but feel the call for new concepts is not always the most desirable outcome. Actually what we need are more robust concepts, something which does not preclude the production of new concepts but also does not exclude renewing existing concepts. The latter is certainly not as glamorous as minting new concepts, but, as the story of megaregions illustrates, it might prove to be a necessary antidote to the theoretical myopia and exaggerated claims to newness and 
conceptual innovation present in some accounts purporting to explain globalization's new urban form.

The second contour relates to methodology and approaches to doing global urban research. It is certainly the case that urban scholars are leaving no stone unturned in the pursuit of new theory production, but what, we ask, can be said about the current state of empirical research (and the methodological approaches we possess) for conceptualizing globalized urbanization. We believe that focusing on questions of agency (who or what is constructing megaregions), process (how are megaregions being constructed), and specific interests (why are megaregions being constructed) offers one important way forward in complementing and/or challenging the current assumptions and beliefs which surround megaregions. We are particularly encouraged by the potential afforded by periodization, but this requires researchers to divert their attention away from the examples of outstanding success to begin considering how the individual trajectories of megaregions compare and how megaregions relate to one another.

The third contour is the issue of temporality. For our part we are encouraged by what we see as something of a 'historical turn' in global urban studies. What we observe is a much closer reading of urban history and an onus on explaining current urban developments by positioning cities in globalization into a much longer trajectory of urban development, expansion and change (see, for example, Brenner and Schmid, 2014; Scott and Storper, 2014; Taylor et al., 2010; Taylor, 2013; Wachsmuth, 2014). Not only is this approach revealing important continuities and discontinuities in urban development, it is noticeable how many claims to newness are in fact not altogether new but the rediscovery and bringing forward of a previous idea or approach ${ }^{4}$. 
In conclusion, we want to confront the main question raised by this book: namely, is the megaregion globalization's new urban form? Spatially, there is no denying the trend is towards more megaregional formations in globalization. Yet, as we have sought to demonstrate in this book, focusing on the temporal aspects of megaregional development reveals no essential connection between megaregions and globalization. What it demonstrates is how we are in a temporally defined scaled moment where the focus is on megaregions as we seek to understand the dynamics of capitalist growth. In the current moment the megaregion concept is of global significance and relevance to academics, political leaders, and policymakers alike. This is not to say that the megaregion concept will necessarily remain so in the future. Put bluntly, what this book argues is that the megaregion concept will only remain the focus of attention for as long as social actors find it useful in advancing their own specific interests (cf. Mayer, 2008). We should not forget that only ten years ago, Taylor and Lang (2004) did not include 'megaregion' in their list of fifty terms accounting for globalization's new urban form. This shows how quickly momentum can gather around a particular spatial imaginary, but also acts as a warning for how quickly it could subsequently disappear. Indeed, Glass offers a useful summation of what for us is the key factor in determining the longevity of the megaregion (or any other spatial imaginary) in framing changing urban form in globalization, across space and time:

$[\mathrm{T}]$ he political sovereignty of proposed spaces such as the megaregion can never be completed - the authority of the megaregion as a viable political space, including its value to continue through time - must be continually reasserted, or else new geographical projects and imaginaries will co-opt the semblance of 
legitimacy which the megaregion as geographical imaginary has constructed. (Glass, 2015, p. 129)

What this reaffirms is our key point. Megaregionalism is as much a political project as it is a story about capitalist processes. For as long as social actors see value - in other words, an ability to exert influence over other centres of social power by using this framing of megaregions to advance their own specific interests - it will continue to be promoted both intellectually and practically. However, if and when a point arises where another spatial imaginary can challenge, overtake, or replace the megaregion in best serving this purpose, the appeal of the megaregion will almost inevitably wane. It is critical to understand that the appearance and/or disappearance of the megaregion concept will not result from some radical change to the spatial form of globalized urbanization, nor will it result from a fundamental shift in the economic logic of agglomeration economics, rather it will result from changes in the political authority of megaregions as a politically viable space of engagement for key social actors. This line of thinking brings us back to the sentiments expressed by August Hecksher (1964) some fifty years ago in the foreword to Jean Gottmann's classic text Megalopolis: The Urbanized Northeastern Seaboard of the United States. To this day the megaregion remains a powerful imaginary for exploring globalization's new urban form; nevertheless, we need to be very careful how we choose to use it because it is very easy for misconceptions to take root. 


\section{References}

Bozick, T. (2013), 'Hampton Roads, Richmond could be "megaregion”', Daily Press, 26 December.

Brenner, N. (2009), 'Open questions on state rescaling', Cambridge Journal of Regions, Economy and Society, 2 (1), 123-139.

Brenner, N. (ed.) (2013), Implosions/Explosions: Towards a Study of Planetary Urbanization, Berlin: Jovis.

Brenner, N. and C. Schmid (2014), 'The "urban age” in question', International Journal of Urban and Regional Research, 38 (3), 731-755.

Connor, K. (2013), 'CaliBaja aims to create economic mega-region', San Diego Source - The Daily Transcript, 29 October.

Cour, J-M. and S. Snrech (1998), Preparing for the Future: A Vision of West Africa in the Year 2020, Paris: OECD.

Cox, K. (1998), 'Spaces of dependence, spaces of engagement and the politics of scale, or: looking for local politics', Political Geography, 17 (1), 1-23.

Davis, M. (2006), Planet of Slums, London: Verso.

Doxiadis, C.A. (1961), Ecumenopolis: Toward the Universal City, Athens: Athens Technological Organization.

Doxiadis, C.A. and J.G. Papaioannou (1974), Ecumenopolis: The Inevitable City of the Future, New York: W \& W Norton.

Fleming, B. (2015), ‘Towards a megaregional future: analysing progress, assessing priorities in the US megaregion project', in J. Harrison and M. Hoyler (eds), 
Megaregions: Globalization's New Urban Form? Cheltenham, UK and Northampton, MA, USA: Edward Elgar, pp. 200-229.

Florida, R. (2014), 'The dozen regional powerhouses driving the U.S. economy', The Atlantic Cities, 12 March.

Florida, R., T. Gulden and C. Mellander (2008), 'The rise of the mega-region', Cambridge Journal of Regions, Economy and Society, 1 (3), 459-476.

Glaeser, E. (2011), Triumph of the City: How Our Greatest Invention Makes Us Richer, Smarter, Greener, Healthier and Happier, Oxford: Pan Macmillan.

Glass, M.R. (2015), 'Conflicting spaces of governance in the imagined Great Lakes megaregion' in J. Harrison and M. Hoyler (eds), Megaregions: Globalization's New Urban Form? Cheltenham, UK and Northampton, MA, USA: Edward Elgar, pp. 119145.

Gleeson, B. (2012), 'The urban age: paradox and prospect', Urban Studies, 49 (5), 931943.

Gottmann, J. (1961), Megalopolis: The Urbanized Northeastern Seaboard of the United States, New York: Twentieth Century Fund.

Harrison, J. (2007), 'From competitive regions to competitive city-regions: a new orthodoxy, but some old mistakes', Journal of Economic Geography, 7 (3), 311-332. Harrison, J. (2013), 'Configuring the new "regional world": on being caught between territory and networks', Regional Studies, 47 (1), 55-74.

Harrison, J. and A. Growe (2014), 'When regions collide - in what sense a new “regional problem”?', Environment and Planning A, forthcoming. Harrison, J. and M. Hoyler (2014), 'Governing the new metropolis', Urban Studies, 51 (11), 2249-2266. 
Harrison, J. and M. Hoyler (2015), 'Megaregions: foundations, frailties, futures', in J. Harrison and M. Hoyler (eds), Megaregions: Globalization's New Urban Form? Cheltenham, UK and Northampton, MA, USA: Edward Elgar, pp. 1-28.

Harvey, D. (2010), The Enigma of Capital, London: Profile Books.

Hecksher, A. (1964), 'Foreword', in J. Gottmann, Megalopolis: The Urbanized Northeastern Seaboard of the United States, Cambridge, MA: MIT Press, pp. vii-viii. Hesse, M. (2015), 'Megaurban regions: epistemology, discourse patterns, big urban business', in J. Harrison and M. Hoyler (eds), Megaregions: Globalization's New Urban Form? Cheltenham, UK and Northampton, MA, USA: Edward Elgar, pp. 29-50. Hidalgo, A. (2014), 'London and Paris: we could soon be part of the same conurbation', The Guardian, 23 January.

Hoyler, M., T. Freytag and C. Mager (2006), ‘Advantageous fragmentation? Reimagining metropolitan governance and spatial planning in Rhine-Main', Built Environment, 32 (2), 124-136.

Jessop, B. (2012), 'Cultural political economy, spatial imaginaries, regional economic dynamics' CPERC Working Paper [English language version of a paper to appear in German in Brand, O., P. Eser and S. Dörhöfer (eds) (2013), Ambivalenzen regionaler Kulturen und Identitäten, Münster: Westfälisches Dampfboot], Lancaster University, available at http://www.lancaster.ac.uk/cperc/docs/Jessop\%20CPERC\%20Working\%20Paper\%202 012-02.pdf (accessed 10 February 2014).

Jessop, B., N. Brenner and M. Jones (2008), 'Theorizing sociospatial relations', Environment and Planning D, 26 (3), 389-401. 
Lovering, J. (1999), "Theory led by policy: the inadequacies of the "new regionalism" (illustrated from the case of Wales)', International Journal of Urban and Regional Research, 23 (2), 379-395.

Mayer, M. (2008), ‘To what end do we theorize sociospatial relations?' Environment and Planning D, 26 (3), 414-419.

Mumford, L. (1968), The City in History: Its Origins, Its Transformation, and Its Prospects, New York: Harvest Books.

Regional Plan Association (2006), America 2050: A Prospectus, New York: RPA. Regional Plan Association (2013), Landscapes: Enabling Partnerships in the Northeast Megaregion, New York: RPA.

Ross, C.L. (2009), 'Introduction’, in C.L. Ross (ed.), Megaregions: Planning for Global Competitiveness, Washington, DC: Island Press, pp. 1-8.

Ross, C.L., D. Lee, E. Meijers and T. Welch (2015), Megaregions, Prosperity and Sustainability, London: Routledge.

Roy, A. (2009), 'The 21st-century metropolis: new geographies of theory', Regional Studies, 43 (6), 819-830.

Samuel, H. (2014), “'London is suburb of Paris” claims mayoral favourite', The Telegraph, 20 January.

Schafran, A. (2014), 'Rethinking mega-regions: sub-regional politics in a fragmented metropolis', Regional Studies, 48 (4), 587-602.

Schafran, A. (2015), 'Beyond globalization: a historical urban development approach to understanding megaregions', in J. Harrison and M. Hoyler (eds), Megaregions: Globalization's New Urban Form? Cheltenham, UK and Northampton, MA, USA: Edward Elgar, pp. 75-96. 
Scott, A.J. (2012), A World in Emergence: Cities and Regions in the 21st Century, Cheltenham, UK and Northampton, MA, USA: Edward Elgar.

Scott, A.J. and M. Storper (2014), 'The nature of cities: the scope and limits of urban theory', International Journal of Urban and Regional Research, DOI: 10.1111/14682427.12134.

Seltzer, E. and A. Carbonell (2011), Regional Planning in America: Practice and Prospect, Cambridge, MA: Lincoln Institute of Land Policy.

Smas, L. and P. Schmitt (2015), 'Brave new "megaregional worlds”? Reflections from a North European perspective', in J. Harrison and M. Hoyler (eds), Megaregions: Globalization's New Urban Form? Cheltenham, UK and Northampton, MA, USA: Edward Elgar, pp. 146-174.

Storper, M. (1997), The Regional World: Territorial Development in a Global Economy, New York: Guilford Press.

Storper, M. (2013), Keys to the City: How Economics, Institutions, Social Interaction, and Politics Shape Development, Princeton, NJ: Princeton University Press.

Taylor, P.J. (2013), Extraordinary Cities: Millennia of Moral Syndromes, WorldSystems and City/State Relations, Cheltenham, UK and Northampton, MA, USA: Edward Elgar.

Taylor, P.J. and R.E. Lang (2004), 'The shock of the new: 100 concepts describing recent urban change', Environment and Planning A, 36 (6), 951-958.

Taylor, P.J. and K. Pain (2007), 'Polycentric mega-city regions: exploratory research from Western Europe', in Regional Plan Association and Lincoln Institute of Land Policy (eds), The Healdsburg Research Seminar on Megaregions: Discussion Papers and Summary, Cambridge, MA: Lincoln Institute of Land Policy, pp. 59-66. 
Taylor, P.J., B. Derudder, M. Hoyler and P. Ni (2013), 'New regional geographies of the world as practised by leading advanced producer service firms in 2010', Transactions of the Institute of British Geographers, 38 (3), 497-511. Taylor, P.J., A. Firth, M. Hoyler and D. Smith (2010), 'Explosive city growth in the modern world-system: an initial inventory derived from urban demographic changes', Urban Geography, 31 (7), 865-884.

UN-Habitat (2010), 'Urban trends: urban corridors - shape of things to come?', UNHabitat Press Release, 13 March, Nairobi: UN-Habitat.

Wachsmuth, D. (2014), 'City as ideology: reconciling the explosion of the city form with the tenacity of the city concept', Environment and Planning D, 32 (1), 75-90. Wachsmuth, D. (2015), 'Megaregions and the urban question: the new strategic terrain for US urban competitiveness', in J. Harrison and M. Hoyler (eds), Megaregions: Globalization's New Urban Form? Cheltenham, UK and Northampton, MA, USA: Edward Elgar, pp. 51-74.

Wheeler, S.M. (2015), 'Five reasons why megaregional planning works against sustainability', in J. Harrison and M. Hoyler (eds), Megaregions: Globalization's New Urban Form? Cheltenham, UK and Northampton, MA, USA: Edward Elgar, pp. 97118.

Zhang, X. (2015), 'Globalization and the megaregion: investigating the evolution of the Pearl River Delta in a historical perspective', in J. Harrison and M. Hoyler (eds), Megaregions: Globalization's New Urban Form? Cheltenham, UK and Northampton, MA, USA: Edward Elgar, pp. 175-199. 
${ }^{1}$ Despite the US-Mexico border recording the highest number of legal crossings of any land border in the world it is also one of the most protected.

${ }^{2}$ We interpret Schafran's $(2014,2015)$ distinction between 'megaregional spaces' and 'spaces of the megaregion' as closely mirroring Cox's (1998) distinction between the 'spaces of engagement' and 'spaces of dependence'.

${ }^{3}$ You might imagine that these questions are more appropriate to ask in relation to megaregional spaces with the least legitimacy, but we would argue they are equally relevant across all megaregional spaces.

${ }^{4}$ The latest example of this is 'planetary urbanization' (Brenner, 2013) which reimagines the idea of ecumenopolis (meaning 'universal city', or a city made of the whole world) put forward by the Greek architect and urban planner Constantinos Doxiadis in the 1960s (Doxiadis, 1961; Doxiadis and Papaioannou, 1974). 